\title{
EVOLUTIVE BEHAVIOR TOWARDS CARDIOMYOPATHY OF TREATED (NIFURTIMOX OR BENZNIDAZOLE) AND UNTREATED CHRONIC CHAGASIC PATIENTS
}

\begin{abstract}
SUMMARY
The aim of this work was to compare the evolution of chronic chagasic untreated patients (UTPs) with that of benznidazole or nifurtimox-treated patients (TPs).

A longitudinal study from a low endemic area (Santa Fe city, Argentina) was performed during an average period of 14 years.

Serological and parasitological analyses with clinical exams, ECG and X-chest ray were carried out. At the onset, 19/198 infected patients showed chagasic cardiomyopathy $(\mathrm{CrChM})$ while 179 were asymptomatic. In this latter group the frequency of $\mathrm{CrChM}$ during the follow-up was lower in TPs compared with UTPs (3.2\% vs 7\%). Within the CrChM group, $2 / 5$ TPs showed aggravated myopathy whereas this happened in 9/14 UTPs. Comparing the clinical evolution of all patients, 5.9\% of TPs and 13\% of UTPs had unfavourable evolution, but the difference is not statistically relevant.

Serological titers were assessed by IIF. Titers equal to or lower than $1 / 64$ were obtained in $86 \%$ of the TPs, but only in $38 \%$ of UTPs. The differences were statistically significant (geometric mean: 49.36 vs. 98.2).

Antiparasitic assessment of the drugs (xenodiagnosis) proved to be effective. The low sensitivity in chronic chagasic patients must be born in mind.

Despite treated patients showed a better clinical evolution and lower antibody levels than untreated ones, it is necessary to carry on doing research in order to improve therapeutic guidelines, according to the risk/benefit equation and based on scientific and ethical principles.
\end{abstract}

KEYWORDS: Chronic Chagas'disease; Treatment; Follow-up; Cardiomyopathy

\section{INTRODUCTION}

The specific antiparasitic treatment of Chagas' disease has been the subject of much controversy.

Many attempts have been done to find an appropriate drug which showed both a highly trypanocidal action and low or null toxicity for the host.

Many drugs have been experimentally assayed, nitrofurane and nitroimidazole derivatives as nifurtimox and beznidazole having shown the highest efficacy against circulating trypomastigotes ${ }^{1,2,11}$, even in their tissue forms ${ }^{3,12,15}$.

Studies conducted to find out how both drugs behave have revealed that they are effective during the acute phase $\mathrm{e}^{8,10,16}$ and in the case of children under $3^{31,37}$ that have already overcome this stage.

If the treatment is good enough to make the antigenic stimulus disappear, we could expect a gradual decrease in anti-T. cruzi antibodies to occur until negative values are confirmed. Although this process is known to occur during the acute phase, it is uncertain whether the same happens during the chronic phase $\mathrm{e}^{4,8,20}$.

It is difficult to evaluate how effective are the therapy results in the case of chronic patients, since Chagas' disease progresses very slowly and patient follow up has to be carried out during long periods. Both conventional parasitological methods (xenodiagnosis and haemoculture), which are known to be scarcely sensitive during this period, and the post-treatment persistence of anti-T. cruzi antibodies have entangled the evaluation.

As both cellular and humoral immunity have been related to the disease $^{24,33}$, the ethiological treatment during the chronic stage has become more controversial.

Some researchers claim that these trypanocidal drugs (nifurtimox and benznidazole) are not useful in preventing Chagas' disease from developing into a chronic infection ${ }^{38}$. 


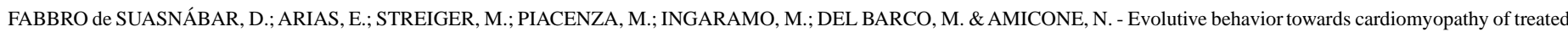
(nifurtimox or benznidazole) and untreated chronic chagasic patients. Rev. Inst. Med. trop. S. Paulo, 42(2): 99-109, 2000.

The aim of our work was to make a follow-up of chronically-infected patients from a low-endemic area, so as to study the natural evolution of the disease in a group of non-treated patients and compare their evolutive behaviour with that of patients undergoing a specific antiparasite treatment.

\section{MATERIAL AND METHODS}

Design: nested cases and controls.

This research was carried out in Santa Fe city (Province of Santa $\mathrm{Fe})$, Argentina, from 1970 to 1998.

Patients suffering from chronic Chagas' disease $(n=492)$ were selected by means of sampling dures carried out in different labor areas. Those who came to our Center, either spontaneously or from other services, for Chagas serology were also included.

The cohort was selected according to actual residence (Santa Fe city and its outskirts) and age (older than 13, younger than 60). Absence of specific antiparasitic treatment was also considered.

Data about migration, habitation, transfusion and maternal serology antecedents were collected by anamnesis.

At the beginning, the population (grouped according to age) was distributed in groups of similar size. During the follow-up period, many patients left the study, in spite of having repeatedly made an appointment. This undoubtedly distorted the groups, but the results are nevertheless reported, in view of the long-term follow up.

All the patients underwent the following tests both at the beginning and during the follow-up period:

a) Three serological Chagas-specific reactions: Direct agglutination with 2-mercaptoethanol (DA-2ME), Indirect Haemoagglutination (IHA) and Indirect Immunofluorescence (IIF) using total human anti-immunoglobulin. Titers equal to or higher than $1 / 32$ for at least two out of the three reactions were considered as positive.

b) Clinical examination, including electrocardiogram (ECG) and chest X-ray (Chest X-r). ECG were classified according to conventional norms accepted for population surveys ${ }^{32}$.

The digestive forms of the Chagas' disease were not investigated.

Those electrocardiographic changes attributable to chronic chagasic myocardiopathy $(\mathrm{CrChM})$ were $^{7,34}$ : complete right bundle branch block (RBBB); left anterior fascicular block (LAFB); LAFB+RBBB; frequent ventricular extrasistole (VE); frequent $\mathrm{VE}$ associated to conduction disturbances; $2^{\text {nd }}$ degree atrioventricular block (AVB); complete AVB; electrical inactivation areas (no antecedents of ischemic cardiopathy).

The infected patients were clinically classified according to KUSCHNIR $^{27}$ :
Group 0: asymptomatic patients (no signs of heart failure), normal ECG and chest X-ray showing normal cardiac area $(\mathrm{CTR}<0.50)$.

Group I: asymptomatic patients (no signs of heart failure). Altered ECG (disturbances suggesting $\mathrm{CrChM}$ ) and chest $\mathrm{X}$-ray showing normal cardiac area.

Group II: Altered ECG. Chest X-ray: enlarged cardiac area. Functional capacity preserved during sligth to moderate efforts.

Group III: Strongly symptomatic patients, from a clinical point of view (signs of heart failure either at rest or during slight efforts), altered ECG and chest X-ray showing important cardiomegaly (grades III or IV) with redistribution of lung flow.

c) The specific antiparasitic treatment included:

Nifurtimox: 5 to $8 \mathrm{mg} / \mathrm{kg} /$ day for 60 days.

Benznidazole: $5 \mathrm{mg} / \mathrm{kg} /$ day for 30 days: half a dose was provided during the first week ${ }^{8,35}$.

It was not given to pregnant women; neither was it supplied to people with hepatic, renal or haematologic failures.

All patients were treated before 1982. At that moment, the administration period suggested for benznidazole was 30 days.

d) Clinical analysis and parasitological xenodiagnosis (Xd) (serial, pre- and post- treatment) were performed on patients receiving trypanocidal drugs. A high percentage $(60 \%)$ of patients underwent this study.

Both treated and untreated chronic chagasic patients were controlled annually or every two years.

\section{Study cohort}

As time passed, the number of patients involved decreased; besides those who returned to highly endemic areas, even for a short period of time, were excluded.

With the aim of having those patients back, home visits were made so as to know why they had stopped attending their checkup sessions. The most important reason is reported to have been the socioeconomic condition of patients, which made it very difficult for them to move around, even within the city itself. Other reasons were migrations and/ or unacceptance of the infection, for fear of losing their job.

In this work we present test results from 198 patients periodically controlled during 8 to 23 years (average: 14 years).

In the study group $(\mathrm{n}=198), 68$ patients received specific antiparasitc treatment: 34 with nifurtimox $(\mathrm{Nx})$ and 36 with benznidazole $(\mathrm{Bz})$. Two patients were treated with both drugs. They were included in tables and figures corresponding to the patient group treated with the last drug given (benznidazole). 


\section{RESULTS}

At the beginning $86 \%$ of the study the infected people was 42 yearold or less, while the most group was between 23 and 42 year-old (Table 1).

Part of the population studied ( $88 \%)$ had been born, or had lived, in highly endemic areas; in addition, $24 \%$ had received blood transfusions. Among the rest of the nonmigrating patients, $8 \%$ had received transfusion; it was definitely proved that $2 \%$ had been born from seropositive mothers, while another $2 \%$ had no migration or transfusion antecedents, and maternal serology was unknown.

The clinical classification of the patients was made only for chronic chagasic myocardiopathy because the digestive forms of Chagas' disease were not studied.

Nineteen out of $198(9.6 \%)$ chronic patients showed electrocardiographical and/or chest X-ray alterations which suggested chagasic ethiology at the beginning of the study, while 179 were going through the latent or undetermined period of the infection, with normal chest $\mathrm{X}$ ray and normal ECG (Figure 1).

In the latter group $(n=179)$, only 63 patients received specific antiparasitic treatment whereas 116 remained untreated.

2/63 infected individuals treated with benznidazole evolved towards a more severe clinical group: $3.2 \%$ (32 and 34 year-old at the beginning of the study, cases 1 and 2, Table 2). For patient 1, frequent VE were observed 3 years after the treatment had finished (GI); LAFB and grade I cardiomegaly are also detected 8 years later (GII). These disturbances are still present after another period of 7 years. For patient 2, changes began to be noticed 5 years after the treatment had ended (LAFB) (GI), and 2 years later he presented grade I cardiomegaly (GII). From them on, he has remained in this group (6 years).

Among the asymptomatic infected individuals who had not been treated with specific antiparasitic drugs 8/116 (7\%) had altered ECG (Figure 1, Table 2).

Patient No. 5 (33 year-old) presented PR 0.26+IRBBB+VE after 12 years (GI), and 6 years later he evolved with first grade $\mathrm{AVB}+\mathrm{RBBB}+\mathrm{LAFB}$ and grade I cardiomegaly (GII).

Case No. 8 (38 year-old) evolved after 9 years, showing $\mathrm{RBBB}+\mathrm{VE}+$ sinus bradycardia (SB) with normal cardiac area (GI). Two years latter he presented grade I cardiomegaly (GII). He has remained in this group until the last control (6 years).

The other 6 patients whose ECG changes shifted from group 0 to group I. Patient No. 4 (31 year-old) evolved to RBBB. Four patients presented single LAFB or LAFB associated to IRBBB or RBBB. At the beginning, they were $25,37,40$ and 41 years old respectively, and changes were observed during a follow-up period of 9 to 14 years. Patient No. 7 showed frequent $\mathrm{VE}, \mathrm{V}_{3}$ to $\mathrm{V}_{6}$ negative (-) $\mathrm{T}$ wave, after having been monitored for 13 years.

Table 1

Age and sex distribuition at the beginning of the study and follow-up period

\begin{tabular}{|c|c|c|c|c|c|c|c|c|c|c|}
\hline \multirow{2}{*}{\multicolumn{2}{|c|}{ Age groups }} & \multicolumn{4}{|c|}{ Treated } & \multicolumn{4}{|c|}{ Untreated } & \multirow[b]{2}{*}{ Total } \\
\hline & & $\mathbf{M}$ & $\mathbf{F}$ & $\mathbf{T}$ & $\begin{array}{l}\text { Years of follow-up } \\
\quad \text { Mean } \pm \text { SD }\end{array}$ & M & $\mathbf{F}$ & $\mathbf{T}$ & $\begin{array}{l}\text { Years of follow-up } \\
\text { Mean } \pm \text { SD }\end{array}$ & \\
\hline \multirow{3}{*}{$86 \%$} & 13 to 22 & 7 & 8 & $\begin{array}{c}15 \\
\text { Nx:6 } \\
\text { Bz:9 }\end{array}$ & $14.7 \pm 4.49$ & 13 & 15 & 28 & $12 \pm 3.18$ & 43 \\
\hline & 23 to 32 & 7 & 18 & $\begin{array}{c}25 \\
\text { Nx:12 } \\
\text { Bz:13 }\end{array}$ & $15.7 \pm 4.35$ & 18 & 22 & 40 & $13.5 \pm 3.58$ & 65 \\
\hline & 33 to 42 & 16 & 8 & $\begin{array}{c}24 \\
\text { Nx:12 } \\
\text { Bz:12 }\end{array}$ & $15 \pm 3.67$ & 13 & 24 & 37 & $14.2 \pm 3.68$ & 61 \\
\hline & 43 to 52 & 2 & 2 & $\begin{array}{c}4 \\
\text { Nx:2 } \\
\text { Bz:2 }\end{array}$ & $15.5 \pm 2.38$ & 6 & 14 & 20 & $14.8 \pm 3.94$ & 24 \\
\hline & $\geq 53$ & & & & & 3 & 2 & 5 & $12.8 \pm 3.85$ & 5 \\
\hline & Total & 32 & 36 & $\begin{array}{c}68 \\
\text { Nx:32 } \\
\text { Bz:36 }\end{array}$ & & 53 & 77 & 130 & & 198 \\
\hline
\end{tabular}

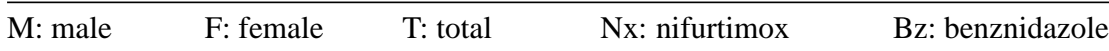




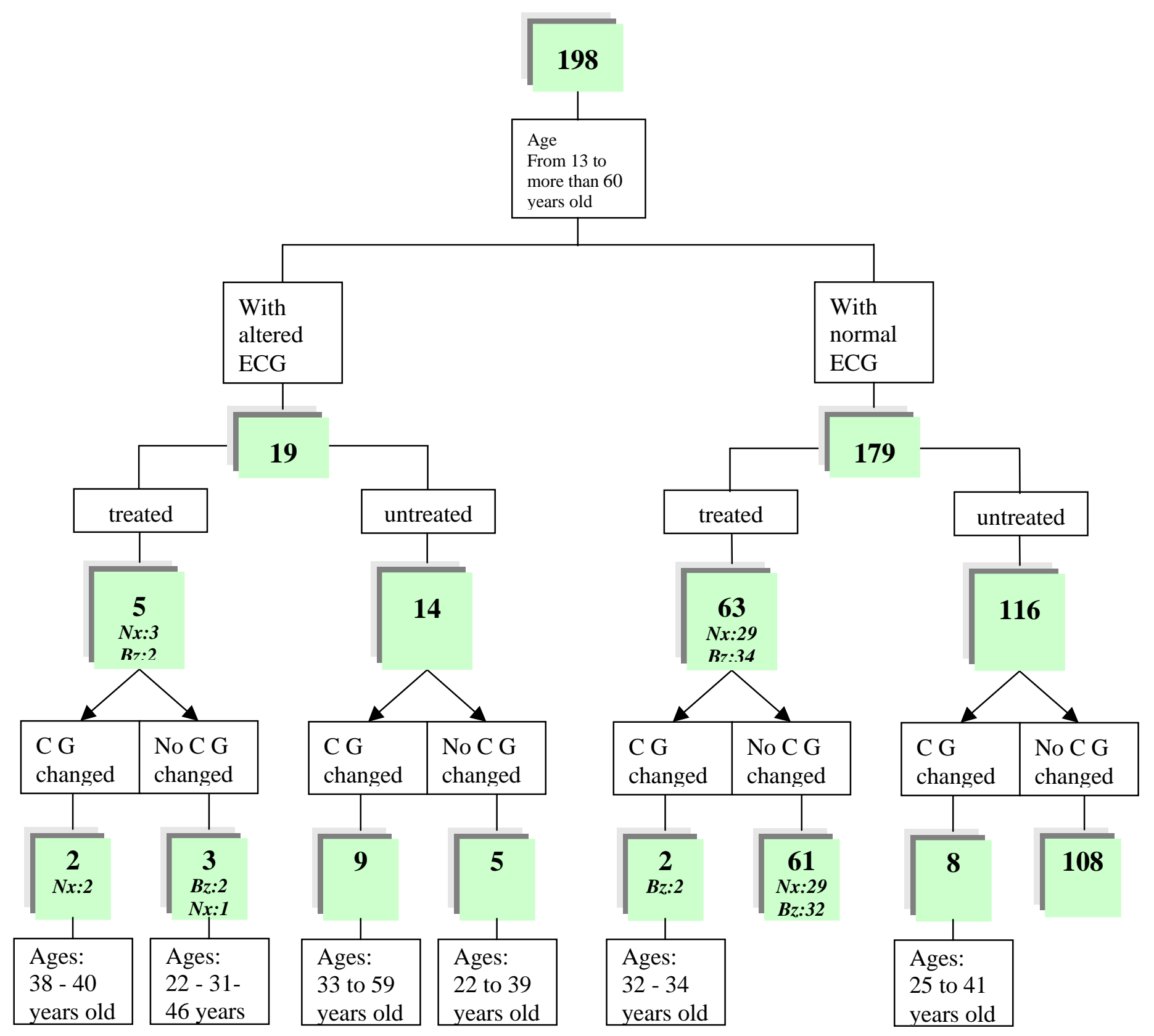

CG changed $=$ clinical group changed

No CG changed $=$ No clinical group changed

$\mathrm{Nx}=$ nifurtimox; $\mathrm{Bz}=$ benznidazole

Fig. 1 - Clinical evolution of symptomatic and asymptomatic chronic chagasic patients according to whether they received or not trypanocidal drugs. 
Table 2

Clinical evolution of chronic chagasic patients in the latent phase at beginning. Developed lesions during the study (10/179)

\begin{tabular}{|c|c|c|c|c|c|c|c|}
\hline No. & AGE & SEX & $\mathrm{T}$ & UT & ICG & FCG & FP \\
\hline 1 & 32 & $\mathrm{~F}$ & $\mathrm{Bz}$ & & G0 & $\begin{array}{c}\text { GII } \\
\text { LAFB+frequent VE } \\
\text { Cardiomegaly grade I }\end{array}$ & 18 \\
\hline 2 & 34 & $\mathrm{M}$ & $\mathrm{Bz}$ & & G0 & $\begin{array}{c}\text { GII } \\
\text { LAFB+SB } \\
\text { Cardiomegaly grade I }\end{array}$ & 13 \\
\hline 3 & 25 & $\mathrm{~F}$ & & $X$ & G0 & $\begin{array}{c}\text { GI } \\
\text { IRBBB+LAFB }\end{array}$ & 11 \\
\hline 4 & 31 & $\mathrm{~F}$ & & $X$ & G0 & $\begin{array}{c}\text { GI } \\
\text { RBBB }\end{array}$ & 13 \\
\hline 5 & 33 & $\mathrm{~F}$ & & $X$ & G0 & $\begin{array}{c}\text { GII } \\
1^{\circ} \mathrm{AVB}+\mathrm{RBBB}+\mathrm{LAFB} \\
\text { Cardiomegaly grade I }\end{array}$ & 18 \\
\hline 6 & 37 & $\mathrm{~F}$ & & $X$ & G0 & $\begin{array}{c}\text { GI } \\
\text { RBBB+LAFB }\end{array}$ & 14 \\
\hline 7 & 37 & $\mathrm{M}$ & & $X$ & G0 & $\begin{array}{l}\text { GI } \\
\text { Frequent VE, V3 to V6 (-)T }\end{array}$ & 13 \\
\hline 8 & 38 & $\mathrm{M}$ & & $X$ & G0 & $\begin{array}{c}\text { GII } \\
\text { RBBB+ VE+SB } \\
\text { Cardiomegaly grade I }\end{array}$ & 17 \\
\hline 9 & 40 & $\mathrm{M}$ & & $X$ & G0 & $\begin{array}{c}\text { GI } \\
\text { LAFB }\end{array}$ & 16 \\
\hline 10 & 41 & $\mathrm{M}$ & & $X$ & G0 & $\begin{array}{c}\text { GI } \\
\text { LAFB }\end{array}$ & 10 \\
\hline
\end{tabular}

T: treated; UT: untreated; ICG: initial clinical group; FCG: final clinical group; FP: follow-up period (years); G0-I-II: clinical group 0-I and II (according to Kuschnir's classification); $1^{\circ} \mathrm{AVB}$ : first-degree atrioventricular block; LAFB: left anterior fascicular block; VE: ventricular extrasistole; SB: sinus bradycardia; IRBBB: incomplete right bundle branch; RBBB: complete right bundle branch block; Bz: benznidazole.

In the untreated patients $(\mathrm{n}=8)$, the mean and median time of clinical evolution $(\mathrm{G} 0 \rightarrow \mathrm{GI})$ during the follow-up period was of 11 years.

In the group of patients with signs or symptoms of $\mathrm{CrChM}(\mathrm{n}=19)$, only 5 patients received specific antiparasitic treatment $(\mathrm{Nx}=3 ; \mathrm{Bz}=2)$ (Table 3); 2 of them ( 38 and 40 year-old) evolved towards a more severe clinical group or died because of chagasic miocardiopathy (cases No. 3 and 4). The latter presented RBBB at the beginning (GI), while VE and grade I cardiomegaly were detected 8 years later. He died after a followup period of 13 years, due to heart arrest (sudden death because of arrhythmia?).

Patient No. 3, showed RBBB+LAFB and normal chest X-ray (GI) in the first control. After 12 years he developed first degree AVB and grade I cardiomegaly (GII).

During the first examination, patient No. 5 showed complete AVB with normal cardiac area, but a low functional capacity due to cardiac frequency (effort-caused dyspnea). Twelve years later, without a pacemaker having been implanted yet, the same symptoms were observed. According to ECG pattern and chest X-ray, the patient belong to Group I, although the clinical symptoms allowed us to classify the case within Group II.

Nine out of fourteen untreated patients with electrocardiographic and/or radiological alterations showed an unfavourable evolution (Table 3) and three of them died:

- a 38 year-old patient (No. 13), initially showing low-voltage QRS complexes with frequent VE, normal cardiac area, and no signs of heart failure. After 4 years, the patient developed a IRBBB with low-voltage complexes and grade I cardiomegaly. After 8 years the same symptoms were observed except for grade II cardiomegaly. Three years afterwards, with grade III-IV cardiomegaly clinical and radiological signs of heart failure, a pacemaker was implanted to solve the bradyarrhythmia. After two years the patient died of heart failure (monitored along 17 years). 


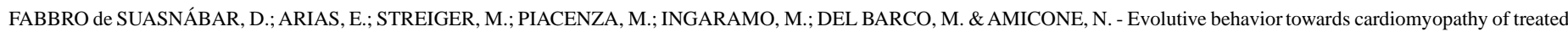
(nifurtimox or benznidazole) and untreated chronic chagasic patients. Rev. Inst. Med. trop. S. Paulo, 42(2): 99-109, 2000.

Table 3

Clinical evolution og chronic patients showing signs or symptoms of chagasic miocardiopathy at beginning of the study

\begin{tabular}{|c|c|c|c|c|c|c|c|c|}
\hline No. & AGE & SEX & $\mathrm{T}$ & UT & ICG & FCG & FP & \\
\hline 1 & 22 & $\mathrm{M}$ & $\mathrm{Bz}$ & & $\begin{array}{c}\text { GI } \\
\text { RBBB } \\
\text { Chest X-ray: normal }\end{array}$ & $\begin{array}{c}\text { GI } \\
\text { RBBB } \\
\text { Chest X-r: normal }\end{array}$ & 11 & \\
\hline 2 & 31 & $\mathrm{~F}$ & $\mathrm{Bz}$ & & $\begin{array}{c}\text { GI } \\
\text { LAFB } \\
\text { Chest X-r: normal }\end{array}$ & $\begin{array}{c}\text { GI } \\
\text { LAFB } \\
\text { Chest X-r: normal }\end{array}$ & 14 & \\
\hline 3 & 38 & M & $\mathrm{Nx}$ & & $\begin{array}{c}\text { GI } \\
\text { RBBB+LAFB } \\
\text { Chest X-r: normal }\end{array}$ & $\begin{array}{c}\text { GII } \\
\text { RBBB+LAFB }+1^{\circ} \mathrm{AVB} \\
\text { Cardiomegaly grade I }\end{array}$ & 14 & \\
\hline 4 & 40 & M & $\mathrm{Nx}$ & & $\begin{array}{c}\text { GI } \\
\text { RBBB } \\
\text { Chest X-r: normal }\end{array}$ & $\begin{array}{c}\text { GII } \\
\text { RBBB+VE } \\
\text { Cardiomegaly grade I }\end{array}$ & 13 & $t$ \\
\hline 5 & 46 & M & $\mathrm{Nx}$ & & $\begin{array}{c}\text { GI-II? } \\
\text { Complete AVB } \\
\text { Chest X-r: normal }\end{array}$ & $\begin{array}{c}\text { GI-II? } \\
\text { Complete AVB } \\
\text { Chest X-r: normal }\end{array}$ & 13 & \\
\hline 6 & 22 & $\mathrm{M}$ & & $X$ & $\begin{array}{c}\text { GII } \\
\text { LAFB } \\
\text { Cardiomegaly grade I }\end{array}$ & $\begin{array}{c}\text { GII } \\
\text { LAFB } \\
\text { Cardiomegaly grade I }\end{array}$ & 10 & \\
\hline 7 & 25 & F & & $X$ & $\begin{array}{c}\text { GI } \\
\text { LAFB } \\
\text { Chest X-r: normal }\end{array}$ & $\begin{array}{c}\text { GII } \\
\text { LAFB+SB } \\
\text { Cardiomegaly grade I }\end{array}$ & 18 & \\
\hline 8 & 32 & $\mathrm{~F}$ & & $X$ & $\begin{array}{c}\text { GII } \\
\text { RBBB+LAFB } \\
\text { Cardiomegaly grade I }\end{array}$ & $\begin{array}{c}\text { GII } \\
\text { RBBB+LAFB } \\
\text { Cardiomegaly grade I }\end{array}$ & 13 & \\
\hline 9 & 33 & $\mathrm{M}$ & & $X$ & $\begin{array}{c}\text { GI } \\
\text { RBBB } \\
\text { Chest X-r: Normal }\end{array}$ & $\begin{array}{c}\text { GII } \\
\text { RBBB } \\
\text { Cardiomegaly grade I }\end{array}$ & 13 & \\
\hline 10 & 34 & $\mathrm{~F}$ & & $X$ & $\begin{array}{c}\text { GI } \\
\text { RBBB+LAFB } \\
\text { Chest X-r: normal }\end{array}$ & $\begin{array}{c}\text { GI } \\
\text { RBBB+LAFB } \\
\text { Chest X-r: normal }\end{array}$ & 10 & \\
\hline 11 & 37 & F & & $X$ & $\begin{array}{c}\text { GI } \\
\text { LAFB } \\
\text { Chest X-r: normal }\end{array}$ & $\begin{array}{c}\text { GI } \\
\text { LAFB } \\
\text { Chest X-r: normal }\end{array}$ & 10 & \\
\hline 12 & 37 & $\mathrm{M}$ & & $\mathrm{X}$ & $\begin{array}{c}\text { GII } \\
\text { LAFB } \\
\text { Cardiomegaly grade I }\end{array}$ & $\begin{array}{c}\text { GIII } \\
\text { IRBBB+LAFB } \\
\text { Cardiomegaly grade II } \\
\text { Signs of heart failure }\end{array}$ & 17 & \\
\hline 13 & 38 & M & & $X$ & $\begin{array}{c}\text { GI } \\
\text { VE low-voltage QRS } \\
\text { complexes } \\
\text { Chest X-1'r: normal }\end{array}$ & $\begin{array}{c}\text { GIII } \\
\text { IRBBB+VE+SB } \\
\text { Cardiomegaly grade III } \\
\text { Signs of heart failure }\end{array}$ & 17 & 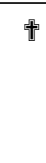 \\
\hline
\end{tabular}


Continuation table 3

\begin{tabular}{|c|c|c|c|c|c|c|c|}
\hline 14 & 39 & $\mathrm{~F}$ & $X$ & $\begin{array}{c}\text { GII } \\
\text { RBBB+LAFB } \\
\text { Cardiomegaly grade I }\end{array}$ & $\begin{array}{c}\text { GII } \\
\text { RBBB+LAFB } \\
\text { Cardiomegaly grade I }\end{array}$ & 11 & \\
\hline 15 & 43 & $\mathrm{~F}$ & $X$ & $\begin{array}{c}\text { GI } \\
\text { LAFB } \\
\text { Chest X-r: normal }\end{array}$ & $\begin{array}{c}\text { GII } \\
\text { LAFB+APE } \\
\text { Effort-caused dyspnea } \\
\text { Cardiomegaly grade I }\end{array}$ & 10 & \\
\hline 16 & 47 & $\mathrm{~F}$ & $X$ & $\begin{array}{c}\text { GII } \\
\text { RBBB+LAFB } \\
\text { Cardiomegaly grade I }\end{array}$ & $\begin{array}{c}\text { GIII } \\
\text { RBBB+LAFB } \\
\text { Cardiomegaly grade III } \\
\text { Signs of heart failure }\end{array}$ & 8 & $\dagger$ \\
\hline 17 & 54 & $\mathrm{M}$ & $X$ & $\begin{array}{c}\text { GII } \\
\text { LAFB } \\
\text { Cardiomegaly grade I }\end{array}$ & $\begin{array}{c}\text { GIII } \\
\text { LAFB+IRBBB+VE } \\
\text { Cardiomegaly grade II } \\
\text { Sign of heart failure }\end{array}$ & 18 & \\
\hline 18 & 59 & $\mathrm{M}$ & $\mathrm{X}$ & $\begin{array}{c}\text { GII } \\
\text { RBBB+LAFB } \\
\text { Cardiomegaly grade I }\end{array}$ & $\begin{array}{c}\text { GIII } \\
\text { RBBB+LAFB+SB } \\
\text { With pacemaker } \\
\text { Cardiomegaly grade III }\end{array}$ & 13 & $t$ \\
\hline 19 & 59 & $\mathrm{M}$ & $\mathrm{X}$ & $\begin{array}{c}\text { GI } \\
\text { IRBBB+LAFB+1 }{ }^{\circ} \text { AVB } \\
\text { Chest X-r: normal }\end{array}$ & $\begin{array}{c}\text { GIII } \\
\text { Complete AVB } \\
\text { with pacemaker } \\
\text { cardiomegaly grade II } \\
\text { Sign of heart failure }\end{array}$ & 8 & \\
\hline
\end{tabular}

†: died; FP: follow-up period (years); ICG: initial clinical group; FCG: final clinical group; T: treated; UT: untreated; GI-II-III: clinical group I, II and III (according to Kuschnir's classification); RBBB: complete right bundle branch block; LAFB: left anterior fascicular block; $1^{\circ} \mathrm{AVB}$ : first-degree atrioventricular block; VE: ventricular extrasistole; SB: sinus bradycardia; IRBBB: incomplete right bundle branch block; APE: atrial premature ectopic; Bz: benznidazole; Nx: nifurtimox.

- a 47 year-old patient (No. 16) with RBBB+LAFB and grade I cardiomegaly evolved to grade III, dying after several events of ventricular fibrillation.

- a 59 year-old patient (No. 18) who at first showed RBBB+LAFB and grade I cardiomegaly, and after 12 years developed symptomatic sinus bradycardia. A pacemaker was implanted, but the patient died 6 months later from cardiac arrest (arrhythmia).

Patient No. 12, 37 year-old, initially showed LAFB and grade I cardiomegaly. After a follow-up period of fifteen years, the patient suffered a stroke and kept on with right hemiparesis two years later. Serological tests were slightly positive during the first 3 years, and then no anti-T. cruzi antibodies (Ab) could be detected, except for a few positive results with direct agglutination tests. The results from $5 \mathrm{Xd}$ were negative.

In this group of untreated patients, the time of evolution from one clinical group to another was highly variable. Those who changed from GI to GII did this within 4 to 10 years $(x=6.4)$. The greatest variations in time were observed in patients whose cardiomyopathy was seen to aggravate $(\mathrm{GII} \rightarrow \mathrm{GIII})$ within 1 to 15 years.
It is necessary to comment on the actual evolution time in patients, as it is not known how many years each chronic patient had been infected. None of them knew they were infected when they first entered the study. Nor did they know when they had acquired the infection.

Considering all the patients $(n=198)$, with or without specific antiparasitic treatment (Figure 2), the $5.9 \%$ of treated patients $(n=68)$ presented clinical group changes during the follow-up period, whereas these modifications were observed in the $13 \%$ of untreated patients $(n=130)$.

Data analysis shows a favourable clinical evolution to exist in treated patients although it is not statistically significant (Chi square test: not significant; $p>0.05$ ) (Fisher exact test: not significant; $p>0.05$ ).

A group of 73 chronically infected patients (without signs or symptoms of $\mathrm{CrChM}$ ) who had undergone a longer monitoring period (over 15 years) showed a favourable clinical evolution. If we include two patients who developed first degree AVB in the group which showed a non favourable evolution, this represents the $8.3 \%(6 / 73)$ and if we exclude them, the $5.5 \%(4 / 73)$. 


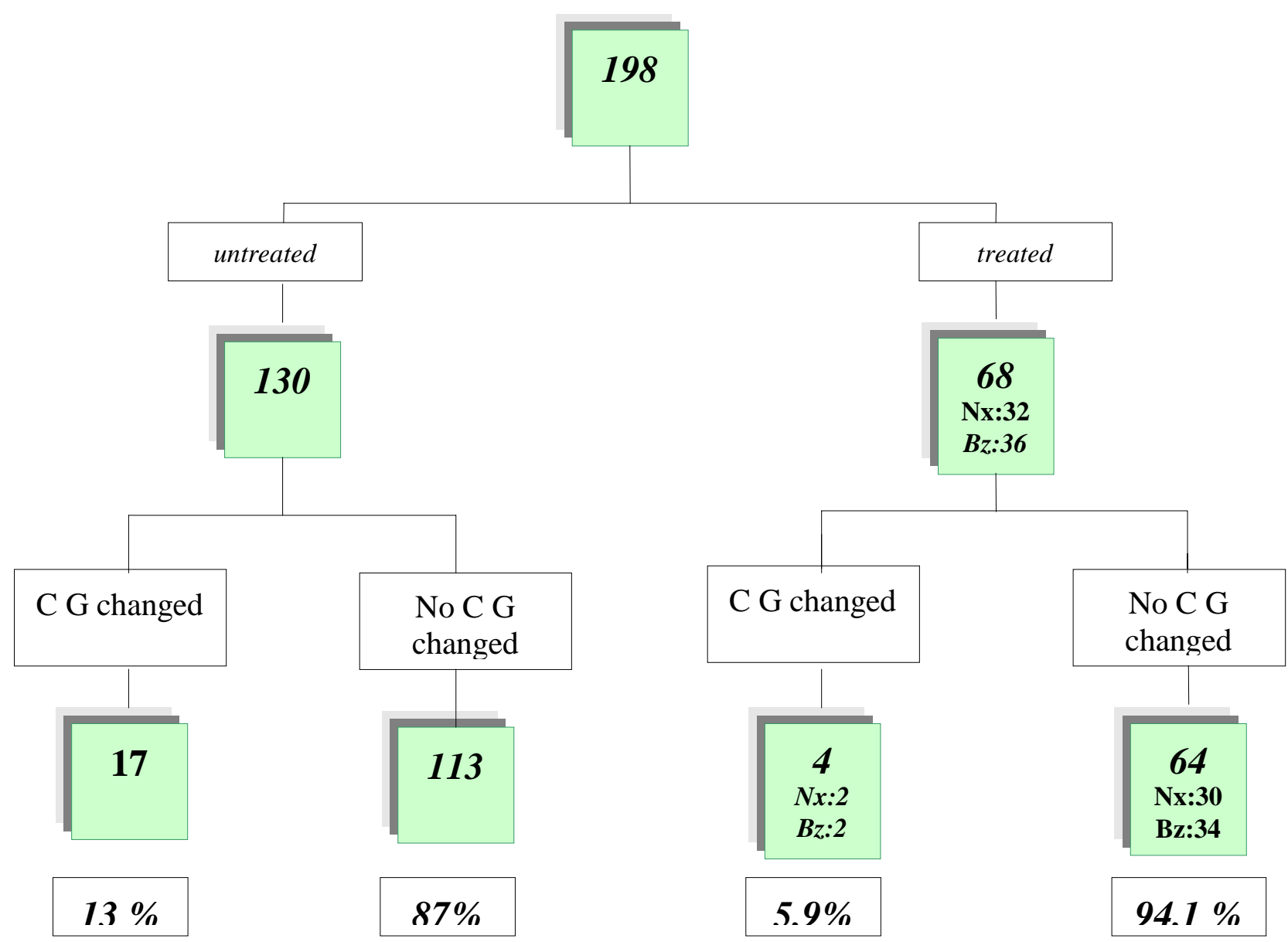

Fig. 2 - Evolutive electrocardiographical and radiological behavior of 198 chronic chagasic patients, with and without specific chemotherapy.

Half of the group received antiparasitic drugs $(n=36)$, and showed a lesser degree of $\mathrm{CrChM}$ when compared with non-treated patients. The sample size does not allow us to arrive to a definite conclusion.

\section{Serological titers}

All the patient's sera drawn during 1995 were simultaneously analysed using indirect immunofluorescence against total Ig antibodies (Ab). Among the 89 sera, 38 belonged to infected treated patients. The majority ( $86 \%$ ) showed antibody titers equal to or lower than $1 / 64$. Two patients who had been treated with antiparasitic drugs at the age of 14 and $15(\mathrm{Nx}=1, \mathrm{Bz}=1)$, showed a progressive decrease in serological titers. Non-reactive results for the three tests were obtained only 6 years after the treatment had finished, and the parasitological tests (Xd) were negative. These two patients, (now 29 and 30 years old respectively) still show no signs or symptoms of $\mathrm{CrChM}$.

Among the 51 sera from infected patients without treatment, $62 \%$ showed serological titers equal to or higher than 1/128. Anti-T. cruzi $\mathrm{Ab}$ were not detected by IIF in the serum from patient No. 8 , described in Table 3. 
Table 4 shows the median and geometric mean of the serological titers by age groups in patients during a mean follow-up period of 15 years:

- In 4A between treated and untreated patients.

- In 4B between patients treated with nifurtimox or benznidazole.

Table 4

Serological titers (IIF) at the end of the study (years of follow-up: mean 15)

A) Treated and untreated patients

\begin{tabular}{ccccccc}
\hline \multirow{2}{*}{$\begin{array}{c}\text { Age groups at } \\
\text { the beginning }\end{array}$} & \multicolumn{6}{c}{ Serological titers } \\
\cline { 2 - 7 } & No. & $\mathrm{m}$ & $\mathrm{gm}$ & No. & $\mathrm{m}$ & $\mathrm{gm}$ \\
\cline { 2 - 7 } & No. & Untreated $(\mathrm{n}=51)$ \\
\hline 13 to 22 & 12 & 32 & 29.5 & 9 & 128 & 101.4 \\
23 to 32 & 14 & 64 & 60.9 & 17 & 128 & 92.3 \\
33 to 42 & 9 & 32 & 47 & 13 & 128 & 100 \\
43 to 52 & 3 & 64 & 64 & 10 & 128 & 104 \\
$\geq 53$ & - & - & - & 2 & 128 & 90.5 \\
\hline
\end{tabular}

B) Patientes treated with Nifurtimox or Benznidazole

\begin{tabular}{|c|c|c|c|c|c|c|}
\hline \multirow{3}{*}{$\begin{array}{l}\text { Age groups at } \\
\text { the beginning }\end{array}$} & \multicolumn{6}{|c|}{ Serological titers } \\
\hline & \multicolumn{3}{|c|}{ Benznidazole $(n=20)$} & \multicolumn{3}{|c|}{ Nifurtimox $(n=18)$} \\
\hline & No. & $\mathrm{m}$ & gm & No. & $\mathrm{m}$ & $\mathrm{gm}$ \\
\hline 13 to 22 & 7 & 32 & 34.9 & 5 & 32 & 27.5 \\
\hline 23 to 32 & 7 & 64 & 57.2 & 7 & 32 & 46.9 \\
\hline 33 to 42 & 5 & 32 & 47.9 & 4 & 32 & 44.7 \\
\hline 43 to 52 & 1 & 32 & 31.6 & 2 & 64 & 63.1 \\
\hline
\end{tabular}

No.: number of serums

m: median

gm: geometric mean

Statistically significant differences $(\mathrm{p}<0.005)$ were observed between IIF-assessed antibody titers of treated patients (geometric mean=49.36) and those of non-treated ones (geometric mean=98.25). These differences were not observed when patients treated with nifurtimox (geometric mean $=41.40$ ) or benznidazole (geometric mean=44.16) were compared (Fischer exact test: not significant; $\mathrm{p}>0.05$ ).

\section{Trypanocidal drug tolerance}

In the group of patients treated with benznidazole, 5 out of $36(13.8 \%)$ did not tolerate the drug, erythema maculopapulatum and nausea being the most frequent symptoms. Afterwards, three of them were treated with nifurtimox.

In the group of patients treated with this last drug, $3 / 32(9.4 \%)$ did not tolerate it and 2 of them had $(+)$ xenodiagnosis after having completed the treatment. Nifurtimox intolerance manifested itself with nausea, vomit and increased transaminase levels.

\section{Parasitological studies}

Serial Xd were carried out on samples from 129 chronic patients. $T$. cruzi was shown in 54 patients (42\%), 38 of which received treatment. All post-treatment parasitological controls were negative (-), except for 2 patients to whom nifurtimox had been administered. They were afterwards treated with benznidazole, the following studies showing that their Xds had become negative.

As regard manifestation of clinical signs (electrocardiographical and/ or radiological alterations) related to the presence or absence of $\mathrm{Xd}$ demonstrable parasitemia, the following data were gathered:

- Only one of the 38 treated showing previous (+) Xd evolved towards a more severe clinical stage, and presented 7 (-) post-treatment serial Xd (case No. 1, Table 2). Two out of the 16 patients who did not receive trypanocidal drugs developed electrocardiographical and/or radiological alterations compatible with $\mathrm{CrChM}$.

- Fifteen of the 75 patients who showed (-) Xd - some of them repeatedly up to 8 times - received treatment with nifurtimox or benznidazole, and 2 evolved towards a $\mathrm{CrChM}$. In the non-treated group ( $n=60), 13$ patients fell ill or got worse.

\section{DISCUSSION}

Our results show that, when comparing data from non-treated patients with those from patients who had received specific antiparasitological treatment, the latter revealed a favourable clinical, electrocardiographical and radiological evolution as well as a decrease in IIF-assessed serological titers.

These findings are similar to those observed in benznidazole-treated patients ${ }^{41}$ and differ from those found for chronically infected people treated with nifurtimox ${ }^{28}$.

In our work differences were not observed as regards the clinical and serological evolution between the patients treated with nifurtimox or benznidazole.

Others authors have experimentally observed a decrease in both anatomopathological lesions ${ }^{1,5,36}$ and anti-T. cruzi Ab level in chronically infected mice treated with trypanocidal drugs (nifurtimox-benznidazole). Besides, there exist certain T. cruzi strains that are known to be more susceptible to a specific chemotherapy than others ${ }^{6}$.

There is evidence supporting the idea that autoimmune phenomena are involved in the fisiopathogenia of $\mathrm{CrChM}$ : in heart histological studies performed on biopsies and necropsies, the lesions found were independent of the "in situ" T. cruzi presence, and the existence of autoimmunity-associated antibodies was also demonstrated ${ }^{17,23}$. However, it is possible that the presence of either the parasite or its specific antigenic components ${ }^{9}$ could contribute to maintain or stimulate these immunological phenomena. 


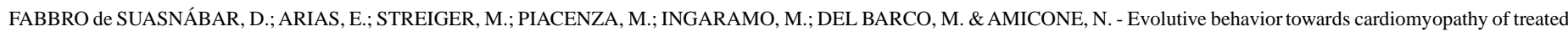
(nifurtimox or benznidazole) and untreated chronic chagasic patients. Rev. Inst. Med. trop. S. Paulo, 42(2): 99-109, 2000.

Others authors also observed a decrease in specific-antibody level in chronic patients previously treated with trypanocidal drugs ${ }^{41}$. During our follow-up, a positive serology persisted, except for 2 patients who were treated at the ages of 14 and 15 . They repeatedly showed titers lower than the thereshold value $(<1 / 32)$, for the three serological reactions, more than 6 years after the treatment had finished. No signs or symptoms of $\mathrm{CrChM}$ were revealed and their parasitological studies (serial Xds) did not show T. cruzi.

The age at which chronic patients received treatment is considered to be important since the lower the age of chronic chagasic treated children, the higher the percentage of negative parasitological and serological studies ${ }^{18,19}$, although the trypanocidal drugs used were shown to be more effective during the acute stage and in children under 3 .

Xd parasitological studies were negative in treated patients, but we must take into account that the low sensitivity of this method during the chronic period does not allow us to assert that complete deparasitation has been achieved as a result of drug action.

The presence or absence of lytic antibodies has been used by some authors ${ }^{21,29}$ as an important element to monitor treatment efficacy, but the complement-mediated lysis test used for those antibodies presents some difficulties from a practical point of view.

In diagnosing and evaluating trypanocidal drug action, it would be greatly useful to deepen studies on the search for new techniques based either on specific $T$. cruzi antigenic components ${ }^{22,25,26}$ or on the parasite DNA recognition. Polymerase chain reaction (PCR) has been assayed to evaluate benznidazole therapeutic action ${ }^{13}$ with encouraging results.

The evolution of treated and untreated asymptomatic chronic patients after 15 years of follow-up is benign since only 5.5\%-8.3\% present symptoms and/or signs of CrChM.

A correlation between $T$. cruzi zymodemes ${ }^{30}$ and the clinical picture has been already shown to exist, but important factors other than the parasite strain would be possibly involved, as the nutritional state of the population under study, the possibility of reinfections, etc.

In spite of their toxicity ${ }^{14,39,40}$, nifurtimox and benznidazole are the best clinically used drugs currently available. We believe it is important to carry on research in order to clarify therapeutic guidelines about the risk/benefit, based on scientific and ethical principles.

\section{RESUMO}

\section{Evolução à miocardiopatia dos infectados chagásicos crônicos tratados (nifurtimox ou benzonidazol) e não tratados}

Para comparar a evolução dos infectados chagásicos crônicos não tratados (UTPs) e tratados (TPs) com nifurtimox ou benznidazol, fez-se um estudo longitudinal numa área de baixa endemicidade (cidade de Santa Fe, Argentina), com média de seguimento de 14 anos.

Em cada controle foram feitas análises sorológicas e parasitológicas, exames clínicos, eletrocardiográficos e radiológicos.
No inicio, 19/198 infectados apresentaram miocardiopatia chagásica crônica (MChCr), enquanto 179 eram assintomáticos. A frequência de $\mathrm{MChCr}$ no seguimento destes últimos foi 3,2\% para os tratados e $7 \%$ para os não tratados. Dos pacientes com $\mathrm{MChCr}$ no início, $2 / 5$ dos tratados e 9/14 dos não tratados agravaram sua miocardiopatia. Comparando a evolução clínica dos infectados, 5,9\% dos tratados e $13 \%$ dos não tratados tiveram evolução desfavorável, mas esta diferença não é estatisticamente significativa.

Na avaliação sorológica por IFI, $86 \%$ dos TPs e só 38\% dos UTPs apresentaram títulos menores ou iguais a 1/64. As diferenças são estatisticamente significativas (média geométrica: 49,36 vs 98,2).

Os xenodiagnósticos seriados realizados, demonstraram efetividade das drogas (considerar a baixa sensibilidade deste método na etapa crônica).

Os pacientes tratados mostraram melhor evolução clínica e mais baixos níveis de anticorpos do que os não tratados. É preciso continuar as investigações para estabelecer pautas terapêuticas mais claras sobre a relação risco-benefício, sustentadas nos princípios científicos e éticos.

\section{ACKNOWLEDGMENT}

The authors are grateful to Laura Macagno, Nidia Garnero, Mariken Risso and Cintia Roodveldt, English Department, Facultad de Bioquímica y Ciencias Biológicas, for their painstaking care in translating this paper into English.

\section{REFERENCES}

1. ANDRADE, S.G. \& ANDRADE, Z.A. - Aspectos anátomo-patológicos e resposta terapêutica na infecção chagásica crônica experimental. Rev. Inst. Med. trop. S. Paulo, 18: 268-275, 1976.

2. ANDRADE, S.G; MAGALHÃES, J.B. \& PONTES, A.L. - Evaluation of chemotherapy with benznidazole and nifurtimox in mice infected with Trypanosoma cruzi strains of different types. Bull. Wld. HIth. Org., 63: 721-726, 1985.

3. ANDRADE, Z. \& BRENER, Z. - Ação da nitrofurazona (5-nitro-2-furaldeídosemicarbazona) sôbre as formas intracelulares do Trypanosoma cruzi na doença de Chagas experimental. Rev. Inst. Med. trop. S. Paulo, 11: 222-228, 1969.

4. ANDRADE, S.G; FREITAS, L.A.; PEYROL, S.; PIMENTEL, A.R. \& SADIGURSKY, M. - Experimental chemotherapy of Trypanosoma cruzi infection: persistence of parasite antigens and positive serology in parasitologically cured mice. Bull. Wld. Hlth. Org., 69: 191-197, 1991.

5. ANDRADE, S.G.; STOCKER-GUERRET, S.; PIMENTEL, A.S. \& GRIMAUD, J.A. Reversibility of cardiac fibrosis in mice chronically infected with Trypanosoma cruzi, under specific chemotherapy. Mem. Inst. Oswaldo Cruz, 86: 187-200, 1991.

6. ANDRADE, S.G.; RASSI, A.; MAGALHÃES, J.B.; FERRIOLI-FILHO, F. \& LUQUETTI, A.O. - Specific chemotherapy of Chagas' disease: a comparison between the response in patients and experimental animals inoculated with the same strains. Trans. roy. Soc. trop. Med. Hyg., 86: 624-626, 1992.

7. ARIAS, E.; STREIGER, M.; DEMONTE, M. et al. - Alteraciones electrocardiográficas en preconscriptos con serología positiva y negativa para infección chagásica en áreas de la provincia de Santa Fe. Rev. argent. Cardiol., 62: 69-74, 1994.

8. BARCLAY, C.A.; CERISOLA, J.A.; LUGONES, H. et al. - Aspectos farmacológicos y resultados terapéuticos del benznidazol en el tratamiento de la infección chagásica. Prensa méd. argent., 65: 239-244, 1978. 


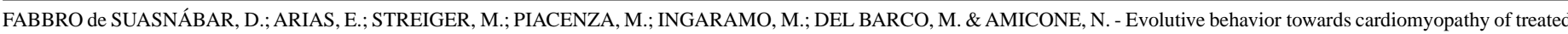
(nifurtimox or benznidazole) and untreated chronic chagasic patients. Rev. Inst. Med. trop. S. Paulo, 42(2): 99-109, 2000.

9. BELLOTTI, G.; BOCCHI, E.A.; MORAES, A.V. de et al. - In vivo detection of Trypanosoma cruzi antigens in hearts of patients with chronic Chagas' heart disease. Amer. Heart J., 131: 301-307, 1996.

10. BOCCA TOURNES, C.L. - La enfermedad de Chagas en período agudo y su tratamiento con el Bay 2502. Bol. chil. Parasit., 24: 24-27, 1969.

11. BRENER, Z. - Study of the action of some active drugs against Trypanosoma cruzi blood forms. Rev. Inst. Med. trop. S. Paulo, 3: 302-306, 1971.

12. BRENER, Z.; TAFURI, W. \& ALMEIDA MARIA, T. - An electron microscope study of Trypanosoma cruzi intracellular forms in mice treated with an active nitrofuran compound. Rev. Inst. Med. trop. S. Paulo, 11: 245-249, 1969.

13. BRITTO, C.; CARDOSO, M.A.; VANNI, C.M. et al. - Polymerase chain reaction detection of Trypanosoma cruzi in human blood samples as a tool for diagnosis and treatment evaluation. Parasitology, 110: 241-247, 1995.

14. CASTRO, J. \& DIAZ DE TORANZO, E. - Toxic effects of Nifurtimox and Benznidazole. Two drugs used against American Trypanosomiasis (Chagas' Disease). Biomed. environ. Sci., 1: 19-33, 1988.

15. CERISOLA, J. - Results of the anti-trypanosoma activity of benznidazole in chronic Chagas infection. In: INTERNATIONAL CONGRESS OF CHEMOTHERAPY, 10, Zurich, 1977.

16. CERISOLA, J.A. - Chemotherapy of Chagas' infection in man. In: Chagas' disease. Washington, Pan American Health Organization, 1977. Pan-Amer. Hlth. Org. Scient. Publ. (347), 1977.

17. CUNHA-NETO, E.; COELHO, V.; GUILHERME, L. et al. - Autoimmunity in Chagas' disease. Identification of cardiac myosin-B13 Trypanosoma cruzi protein crossreactive T cell clones in heart lesions of a chronic Chagas' cardiomyopathy patient. J. clin. Invest., 98: 1709-1712, 1996.

18. DE ANDRADE, A.L.; ZICKER, F.; DE OLIVEIRA, R.M. et al. - Randomised trial of efficacy of benznidazole in treatment of early Trypanosoma cruzi infection. Lancet, 348: 1407-1413, 1996.

19. DEL BARCO, M.; STREIGER, M.; ARIAS, E.; FABBRO, D. \& AMICONE, N. Respuesta al tratamiento en niños con infección chagásica crónica. Medicina (B. Aires), 53: 78, 1993.

20. FERREIRA, H.O. - Tratamento da forma indeterminada da doença de Chagas com nifurtimox e benzonidazol. Rev. Soc. bras. Med. trop., 23: 209-211, 1990.

21. GALVÃO, L.M.; NUNES, R.M.; CANÇADO, J.R.; BRENER, Z. \& KRETTLI, A.U. Lytic antibody titre as a means of assessing cure after treatment of Chagas' disease: a 10 years follow-up study. Trans. roy. Soc. trop. Med. Hyg., 87: 220-223, 1993.

22. GAZINELLI, R.T.; GALVÃO, L.M.; KRAUTZ, G. et al. - Use of Trypanosoma cruzi purified glycoprotein (GP57/51) or trypomastigote-shed antigens to assess cure for human Chagas' disease. Amer. J. trop. Med. Hyg., 49: 625-635, 1993.

23. GRUPPI, A.; GEA, S.; MORETTI, E. \& VOTTERO-CIMA, E. - Human antibodies against T. cruzi exoantigens recognizing parasite surface antigens and heart tissue components Int. Arch. Allergy Appl. Immunol., 90: 119-123, 1989.

24. HUDSON, L. - Autoimmune phenomena in chronic chagasic cardiopathy. Parasit. today, 1: $6,1985$.

25. KRAUTZ, G.M.; COUTINHO, M.G.; GALVÃO, L.M.C.; CANÇADO, J.R. \& KRETTLI, A.U. - Antígenos solúveis liberados por tripomastigotas de Trypanosoma cruzi utilizados no teste de ELISA para detectar cura em pacientes chagásicos após tratamento. Rev. Soc. bras. Med. trop., 27: 199-207, 1994.

26. KRAUTZ, G.M.; GALVÃO, L.M.; CANÇADO, J.R. et al. - Use of a 24-kilodalton Trypanosoma cruzi recombinant protein to monitor cure of human Chagas' disease. J. clin. Microbiol., 33: 2086-2090, 1995.
27. KUSCHNIR, E. - Estudios hemodinámicos en la cardiopatía chagásica, con técnicas de radiotrazadores. In: POSSE, R.; MOUZO, G. \& BARRIO, N., ed. Enfermedad de Chagas. Buenos Aires, Reunión Internacional Sobre Enfermedad de Chagas, 1981. p. 123-130.

28. LIBONATTI, E.; MANZULLO, E.; DARRAIDOU, M. et al. - Seguimiento longitudinal de 4.441 chagásicos crónicos en nueve años. Buenos Aires, Asociación Médica Argentina, 1979. (Premio Humberto Ruggero).

29. MARTINS-FILHO, O.A.; PEREIRA, M.E.; CARVALHO, J.F.; CANÇADO, J.R. \& BRENER, Z. - Flowcytometry, a new approach to detect anti-live trypomastigote antibodies and monitor the efficacy of specific treatment in human Chagas' disease. Clin. Diag. Lab. Immunol., 2: 569-573, 1995.

30. MONTAMAT, E.; DE LUCA D'ORO, G.; GARDENAL, C. \& BLANCO, A. Polimorfismo enzimático en poblaciones de Trypanosoma cruzi. In: REUNIÓN ANUAL DE LA SOCIEDAD ARGENTINA DE PROTOZOOLOGÍA, 13, Buenos Aires, 1994. p. B11.

31. MOYA, P.; PAOLASSO, R.D.; BLANCO, S. et al. - Tratamiento de la enfermedad de Chagas con nifurtimox durante los primeros meses de vida. Medicina (B. Aires), 45: 553-558, 1985.

32. NOMENCLATURA Y CRITERIO DE DIAGNÓSTICO ELECTROCARDIOGRÁFICO EN LA CARDIOPATÍA CHAGÁSICA CRÓNICA. Buenos Aires, Programa de Salud Humana Ministerio de Salud y Acción Social, 1985.

33. ROTTEMBERG, M.E.; DE TITTO, E.; CARDONI, A.L. \& SEGURA, E. - Respuesta inmune en la infección con Trypanosoma cruzi. Rev. argent. Microbiol., 23: 101$121,1991$.

34. SCHENONE, H.; PEREZ OLEA, J.; CONTRERAS, M. \& BORGOÑO, J.M. - Cardiopatía chagásica crónica en Chile. Frecuencia de electrocardiogramas alterados en 13.515 habitantes rurales y periurbanos de áreas de endemia chagásica con serología positiva o negativa. Bol. chil. Parasit., 43: 18-21, 1988.

35. SCHMUÑIS, G.A. - La Tripanosomiasis Americana como problema de Salud Pública. In: Chagas' Disease and the nervous system. Washington, Pan American Health Organization, 1994. Pan Amer. Hlth. Org. Scient. Publ., (547), 1994.

36. SEGURA, M.A.; MOLINA DE RASPI, E. \& BASOMBRÍO, M.A. - Reversibility of muscle and heart lesions in chronic, Trypanosoma cruzi infected mice after late trypanomicidal treatment. Mem. Inst. Oswaldo Cruz, 89: 213-216, 1994.

37. STREIGER, M.; FABBRO, D.; DEL BARCO, M.; BELTRAMINO, R. \& BOVERO, N. - Chagas congénito en la ciudad de Santa Fe. Diagnóstico y tratamiento. Medicina (B. Aires), 55: 125-133, 1995.

38. TEIXEIRA, A.R.; CUNHA NETO, E.; RIZZO, L.V. \& SILVA, R. - Trypanocidal nitroarene treatment of experimental Trypanosoma cruzi infection does not prevent progression of chronic-phase heart lesions on rabbits. J. infect. Dis., 162: 1420, 1990.

39. TEIXEIRA, A.R.; CÓRDOBA, J.C.; SOUTO MAIOR, I. \& SOLORZANO, E. - Chagas' disease: lymphoma growth in rabbits treated with Benznidazole. Amer. J. trop. med. Hyg., 43: 146-158, 1990.

40. TEIXEIRA, A.R.; CALIXTO, M.A. \& TEIXEIRA, M.L. - Chagas' disease: carcinogenic activity of the antitrypanosomal nitroarenes in mice. Mutat. Res., 305: 189-196, 1994.

41. VIOTTI, R.; VIGLIANO, C.; ARMENTI, H. \& SEGURA, E. - Treatment of chronic Chagas' disease with benznidazole: clinical and serologic evolution of patients with long-term follow up. Amer. Heart J., 127: 151-162, 1994.

Received: 13 October 1999

Accepted: 27 December 1999 